\title{
A brief review on fishes of the Caura River, Venezuela
}

\section{Summary}

We present a summary of our studies on the Caura River Basin in Venezuela. We document the presence of 460 species of fishes based on our expeditions, the published literature and scientific collections in international museums. The Characiformes are the most diverse order with 225 (49\%) species followed by the Siluriformes with 140 (30\%) species, Perciformes (mainly Cichlids) with 42 (9\%) species and Gymnotiformes with $29(6 \%)$ species. Approximately 400 species are found at low elevations close to the confluence with the Orinoco River, while163 species live in the upper portions of the basin. The human communities of the Caura River Basin depend upon the river for food, transportation, recreation, their livelihoods and their cultures. It is critical to acknowledge the factors that threaten human and biotic health within the basin, and it is urgent to implement adaptive management protocols for achieving conservation of healthful environments.

A vast section Venezuelan Guayanese region is drained by the 700-km-long Caura River. The Caura River Basin is located in the eastern sector of Bolívar State (3o37'-7o47'N and 63o23'-65o35' W). The river originates in the southern highlands of the Guayana Shield 2,000meters above mean sea level and flows north to join the Orinoco River at Puerto Las Majadas (Figure 1). The river basin covers approximately $45,336 \mathrm{~km}^{2}$, which is $20 \%$ of the total surface of Bolívar State or $5 \%$ of Venezuela. The principal rivers contained within the basin are the Sipapo, Mato, Nichare, Cusimi, Yudi, Kakada, Erebato, Arichi and Merewari Rivers on the western margin and the Tigrera, Tacoto, Pablo, Yuruani, Chanaroand Waña Rivers on the easternmargin. ${ }^{1}$

The largest expanse of the river basin are low lands that are almost entirely covered (ca.90\%) by relatively pristine, evergreen, flooded, gallery and savanna forests. The basin cuts through very old geological formations: The Imataca, Pastora and Roraima Geological Provinces. The river basin is structured by a rocky/white sand, and very old granitic beds, with rapids and cataracts. Beaches of white sand and muddy backwaters are common throughout the basin. The river water varies in color and in chemistry. Lowland rivers, especially near the mouth in the Orinoco River, are white highly opaque waters that are slightly basic. In high elevations and in several tributaries such as the Nichare River, there are black acidic, tea-colored but transparent waters. The Caura River is a major tributary of the Orinoco River only preceded in size by the basins of the Apure, Caroní, and Upper Orinoco rivers. Due to its origin and geological development the basin is heterogeneous in physical structure with rapids and cataracts in upper sectionsand a mixture of back waters, sandy beaches and lagoons in the lower sections. An impressive cataract (Salto Para) divides the upper from the lower RioCaura. ${ }^{1,2}$

The watershed of the Caura River contains thousands of species of plants and animals, many endemics to the Guayana Shield or the OrinocoRiverBasin. ${ }^{3}$ The vegetation of the Caura River is very diverse; more than 1300 plant species have been identified from the Basin. ${ }^{3}$ Current data reveal that inland forests cover approximately $90 \%$ of the watershed while the remaining $10 \%$ of the watershed consists of flooded forests and non-forest vegetation..$^{1,3}$ Between rocks in rapids and cataracts are beds of unique aquatic plants of the family
Volume 8 Issue 5 - 2019

\author{
Barry Chernoff, Antonio Machado Allison \\ College of the Environment, Wesleyan University, USA
} Correspondence: Antonio Machado Allison, College of the
Environment, Wesleyan University, USA,

Emailmachado.alliso@gmail.com

Received: September 10, 2019 | Published: October 31, 2019

Podostemonaceae that are only found within South America on the Guyana and Brazilian Shields. The terrestrial wild life comprises approximately 475 species of birds, 168 species of mammals, 13 amphibian species, and 23 species of reptiles. ${ }^{1,3}$

The fish fauna contains approximately 460 species, of which some are endemic for the basin and some are marvelously beautiful and important for the commercial aquarium trade. Most of the species, ca. 400, are reside in the low elevations below Salto Para near the confluence with the Orinoco River. Above Salto Para there are 163 species in the upper portions of the basin. Furthermore, several macroinvertebrate crustaceans (crabs and shrimps) and aquatic insects form part of the splendid aquatic community. ${ }^{1,46}$

The majority of the fishes are contained in a few orders. The Order Characiformes is the most diverse with around 225(49\%)species followed by the Siluriformes with $140(30 \%)$ species, Perciformes (mainly Cichlids) with $42(9 \%)$ species and Gymnotiformes with $29(6 \%)$ species. There are also miscellaneous groups including the stingrays (Potamotrygonidae), sardines (Engraulidae and Pristigasteridae), soles (Achiridae), guppies and annual fishes (Cyprinodontiformes), and the river eel(Synbranchiformes). ${ }^{7-11}$

The Caura River is the lifeblood of many human communities. People depend upon the river for food, transportation, recreation, their livelihoods and their cultures. The fish fauna and vertebrate wildlife are very important for the maintenance of human communities. The main sources of food and protein for people include many fishesand mammals. For example, fishes such as the aimara (Hopliasmacrophthalmus), pike fishes (Acestrorhynchusspp) and ciclids(Biotodoma) are usually captured with hooks or traps, and mammals such as danta(Tapirusterrestris), and lapas (Agouti paca) are hunted with arrows. ${ }^{12-14}$

The basin forms a part of the homelands of the Ye'kuana people whoareextremelycarefulintheirmanagementofandappreciationfor their natural resources. The high environmental quality of the Caura River Basin, especially from the Raudal La Mura or Cinco Mil to the headlands, is due in large measure to their excellent stewardship. In short, the Caura River and its basin serve as critical habitat for all species of the region, including humans.

Nonetheless, the region is facing immediate threats that could easily change the pristine nature of the environment. Deforestation due to logging in the southern part of the basin, increasing population growth, colonization and habitat degradation in the northernpart of the basin, a plan to divert significant amounts of water from the 
Caura for a hydroelectric facility in the Caroni, illegal hunting and over-exploitation of fisheries below Salto Pará by nonindigenous fishermen, and more recently, the exploitation of minerals promoted through the Orinoco Mining Arch, are all exerting serious pressures upon this uniquewatershed.

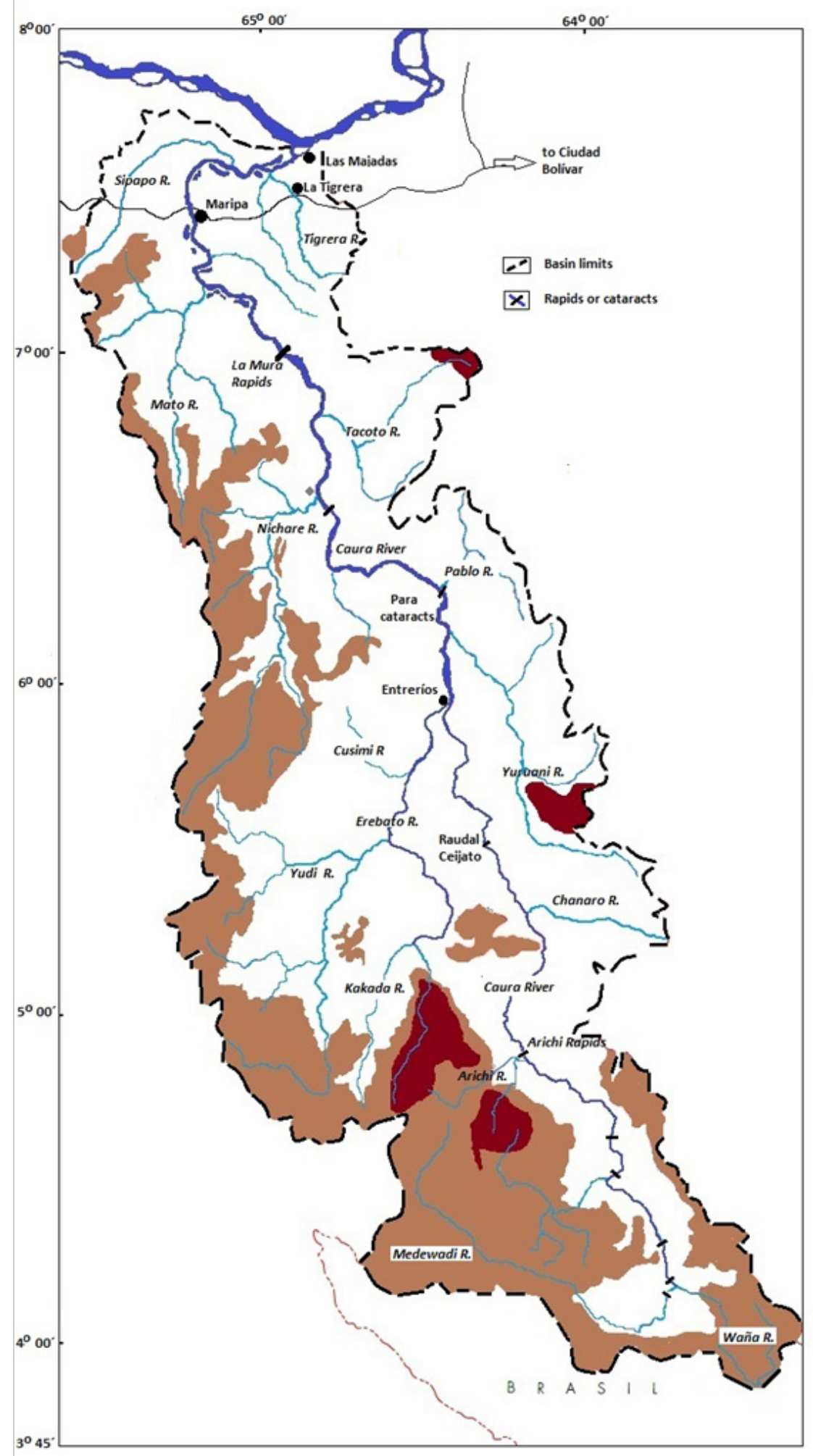

Figure I The watershed of the Caura River. 
The Caura River Basin represent one of the largest tracts of pristine Guayana Shield forest remaining in the world. The aquatic environments of the Caura River, especially above Raudal Cinco Mil, are also in excellent environmental condition shown by the extraordinary richness of fish species compared to other basins in Venezuela for which it is urgent to promote a conservation management in order to protect the basin. ${ }^{10,11}$

- Stop the Orinoco Mining Arch Program and all development plans that might cause changes in the natural hydrologic cycle of the Caura River Basin including dams, water diversions and major riparian changes.

- Perform a migratory fish study.

- Establish a three-year program on sustainable fishing in the Lower Caura.

- Establish a follow-up monitoring program for the watershed.

- Develop a corridor to protect the flooded forests (up to a 50-year flood cycle).

- Implement educational and public outreach programs about the importance of aquatic ecosystems.

- Prohibit the introduction of exotic aquatic species.

- Restore riparian forests below Cinco Mil rapids.

- Develop management plans for the sustainable harvest of the following plant species: Ocoteacymbarum, Vochysiavenezuelana (used for making boats), Acosmiumnitens, Geonomadeversa (used in house construction) and Heteropsisflexuosa (used in making baskets and construction).

- Provide immediate protection, as part of a general conservation plan, to the following areas: Raudal Cejiato, Kakada River, the backwaters and flooded lagoons close to Entreríos, the Raudal Suajiditu and the region just above Salto Pará, El Playón and surrounding areas, the Nichare and Tawadu Rivers, the flooded lagoons close to Boca de Nichare and the Takoto River near Raudal Cinco Mil.

\section{Acknowledgements}

None.

\section{Funding}

None.

\section{Conflicts of interest}

The author declares that there are no conflicts of interest.

\section{References}

1. Chernoff B, Machado-Allison A, Riseng K. A Biological Assessment of the Aquatic Ecosystems of the Caura River Basin, Bolívar State, Venezuela. RAP Bulletin of Biological Assessment. Conservation International Washington DC. 2003.

2. Vispo C, Knab-Vispo C. Plants and Vertebrates of the Caura's Riparan Corridor: Their Biology, Use and Conservation. Scientia Guaianae. 2003. 12.

3. Rosales J, Hubber O. Ecología de la Cuenca del Río Caura, Venezuela. I. Caracterización General. Scientia Guaianae. 1996;6: 1-131.

4. Lasso C, Machado-Allison A, Taphorn D, et al. The Fishes of the Caura River Basin, Orinoco Drainage, Venezuela: Annotated Checklist. Scientia Guaianae. 2003;12:223-245.

5. Ferrer AD, Lew C, Vispo F, et al. Uso de la fauna silvestre y acuática por comunidades del bajo río Caura (Guayana Venezolana). Biota Colombiana. 2013;14(2): 33-44.

6. González N, Echevarría G, Dazaand F, et al. Illustrated list of additions to the ichthyofauna of the Caura River, Venezuela. Cheklist, 2012;8(1):4352.

7. Machado Allison A, Chernoff B, Silvera C, et al. Inventario de los peces de la cuenca del río Caura, Estado Bolívar, Venezuela. Acta Biologica Venezuelica.1999;19(4):61-72.

8. Knab-Vispo C, Rosales J, Rodríguez G. Observaciones sobre el uso de plantas por los Ye'kwana en el bajo río Caura. In: Ecología de la Cuenca del Río Caura. Huber O, J. Rosales. Scientia Guaianae. 1997. p.211-257.

9. Lasso CC, Vispo, O Lasso Alcalá. Composition of the ichthyofauna of nine floodplains lakes of the Caura river, Southern Venezuela. Scientia Guaianae. 2003;12:273-296.

10. Machado Allison A. The conservation of aquatic ecosystems of the Orinoco River basin. Journal of Fish Biology. 2016;58-59.

11. Machado Allison A, Chernoff B, Provenzano F, et al. Identificación de áreas prioritarias de conservación en la cuenca del Río Caura, Estado Bolívar, Venezuela. Acta Biológica Venezuelica, 2002;22 (3-4):37-65..

12. Silva MN. La percepción Ye'kwana del entorno natural. In: Ecología de la Cuenca del Río Caura. Rosales J, Huber O. editors. Scientia Guaianae. 1997. p.65-84.

13. Vispo C. Uso criollo actual de la fauna y su contexto histórico en el bajo Caura. Memorias Sociedad de Ciencias Naturales La Salle. 2000;149:115-144.

14. Vispo C, Rosales J, Knab Vispo C. Ideas on a conservation strategy for the Caura's riparian ecosystem In: Plants and Vertebrates of the Caura'sRiparan Corridor: Their Biology, Use and Conservation. C. Vispo, Knap Vispo C. editors. Scientia Guaianae. 2003. p. 441-481. 